\title{
REFORMA AGRARIA DI INDONESIA
}

\author{
Retno Sulistyaningsih \\ Magister Kenotariatan, Fakultas Hukum, Universitas Airlangga \\ e-mail: retnosulistyaningsih2@gmail.com
}

\begin{abstract}
ABSTRAK
Tujuan utama pembaharuan agraria di Indonesia yakni memberikan kesejahteraan kepada seluruh lapisan masyarakat. Hal ini diupayakan Pemerintah melalui penyusunan kebijakan di bidang pertanahan, meskipun dalam perkembangannya terdapat kebijakan-kebijakan yang seolah mencederai falsafah dan prinsip hukum yang ada di dalam UUPA. Penelitian normatif yang menggunakan metode pendekatan perundang-undangan ini menunjukkan bahwa dalam pelaksanaan reforma agraria yang telah dilakukan oleh pemerintah, masih meninggalkan permasalahan utama yang dihadapi di bidang pertanahan yang menimbulkan konflik atau sengketa di bidang pertanahan khususnya legalisasi dan redistribusi tanah yang meskipun memberikan dampak positif bagi masyarakat namun juga mampu menjawab permasalahan mengenai sengketa pertanahan yang sebenarnya merupakan salah satu tugas utama yang harus diselesaikan dalam melaksanakan reformasi agraria. Peneltitian ini menyarankan pentingnya evaluasi terhadap kebijakan-kebijakan di bidang pertanahan dan tetap memperhatian falsafah maupun prinsip-prinsip dasar yang ada di dalam UUPA sehingga tujuan dari pembaharuan agraria dapat berjalan sebagaimana mestinya dan dapat memberikan dampak kesejahteraan kepada seluruh lapisan masyarakat.
\end{abstract}

Kata Kunci: Pembaruan Agraria; UUPA; Hukum Agraria

\begin{abstract}
The main purpose of agrarian reform in Indonesia is to provide welfare to all levels of society. The Government was strive on this issue through formulating policies in the land sector, even though in practice there are policies that seem to injure the philosophy and legal principles contained in the UUPA. This normative research that uses the statute approach method shows that in the implementation of agrarian reform that has been carried out by the government, it still leaves the main problems faced in the land sector that cause conflicts or disputes in the land sector, especially land legalization and redistribution although has a positive impact on society but is also able to answer problems regarding land disputes which is actually one of the main tasks that must be resolved in implementing agrarian reform. This research suggests the importance of evaluating policies in the land sector while still paying attention to the philosophy and basic principles contained in the UUPA so that the objectives of agrarian reform can run properly and can have a welfare impact on all levels of society.
\end{abstract}

Keywords: Agrarian Reform; UUPA; Agrarian Law

\section{PENDAHULUAN}

Perundang-undangan sebagai lex generalis dalam hukum pertanahan saat ini masih tetap Undang-Undang Nomor 5 Tahun 1960 tentang Peraturan Dasar Pokok-Pokok Agraria (UUPA). UUPA merupakan pedoman utama sebagai bentuk tindak lanjut dari Pasal 33 ayat (3) Undang-Undang Dasar Negara Republik Indonesia Tahun 1945 (UUD 1945), yakni sebuah pengaturan mengenai bumi, air, dan kekayaan alam yang ada di dalamnya sebagai amanat dari konstitusi. Dalam sepuluh pasal yang ada di UUPA, sudah diatur perihal dasar-dasar yang dapat dijadikan pedoman dalam kaitannya dengan Sumber Daya Alam (SDA), meskipun dari sepuluh pasal tersebut hanya terdapat satu pasal yang mengatur SDA selain tanah sebagaimana yang diatur di Pasal 8 UUPA yakni ada pula bidang pertambangan dan lain- 
lainnya. UUPA terdiri dari 58 pasal yang didominasi oleh pengaturan tentang pertanahan, sehingga pada saat penerbitannya disebut sebagai Undang-Undang Pertanahan, yang kemudian dalam perkembangannya ditambahkan ketentuan-ketentuan yang tidak hanya menyangkut pertanahan. ${ }^{1}$

Salah seorang perumus naskah rancangan UUPA yaitu Boedi Harsono, memberikan pendapat yang sama perihal tersebut. Panitia perumus naskah rancangan UUPA memberi nama "Undang-Undang tentang Pokok-Pokok Dasar Hukum Tanah", sedangkan Panitia Soewahjo sebagai pihak yang menyiapkan rencana UUPA beranggapan bahwa nama tersebut diubah menjadi "Undang-Undang tentang Peraturan Dasar Pokok-Pokok Agraria". ${ }^{2}$

Pada tahun 1960-an sebagai awal pelaksanaan reforma agraria mengalami banyak kegagalan, karena tidak jarang banyaknya kecurigaan dan kesalahpahaman yang hadir di tengah-tengah masyarakat. Terlebih permasalahan semakin memanas saat reforma agraria disederhanakan menjadi penyerobotan tanah milik "tuan tanah". Dimana undang-undang yang seharusnya dapat menaungi kepetingan kesejahteraan masyarakat seolah menjadi pedang yang menusuk rakyat itu sendiri karena kelemahannya dalam menentukan karakteristik sosial masyarakat dalam menjelaskan mengenai "tuan tanah". Tuan tanah merupakan penyebutan untuk pemilik tanah di atas plafon (ceiling). ${ }^{3}$

Dalam perkembangannya, UUPA seolah memiliki orientasi yang berubah seiring dengan kebijakan-kebijakan ekonomi yang cenderung berfokus pada pertumbuhan ekonomi dibandingkan dengan pemerataannya. Sehingga beberapa tugas yang dimiliki oleh UUPA diambil oleh undangundang sektoral lainnya, seperti Undang-Undang No. 5 Tahun 1967 tentang Kehutanan (telah diganti dengan Undang-Undang No. 41 Tahun 1999),

1 Soetiknjo Iman. (1987). Proses Terjadinya UUPA, Peranserta Seksi Agraria Universitas Gadjah Mada. Yogyakarta: Gadjah Mada University Press, h. 190.

2 Boedi Harsono. (1999). Hukum Agraria Indonesia, Sejarah Pembentukan UUPA, Isi dan Pelaksanaannya. Jakarta: Djambatan, h. 129.

${ }^{3}$ Febrie Hastiyanyo. "Perencanaan Pembangunan dan Gerqakan Sosial dalam Reforma Agraria di Indonesia”. Jurnal Studi Kepemerintahan. Volume 4 Nomor 2 September 2019, h. 21.
Undang-Undang No. 11 Tahun 1967 tentang Pertambangan (telah diganti dengan Undang-Undang No. 22 Tahun 2001), Undang-Undang No. 11 Tahun 1974 tentang Pengairan (dinyatakan tidak berlaku melalui UU No. 7 Tahun 2004 tentang Sumber Daya Air), dan peraturan perundang-undangan yang lain. Berbagai perundang-undangan yang telah disebut di atas, pada kenyataannya tidak menjadikan UUPA sebagai pedomannya namun langsung merujuk pada Pasal 33 ayat (3) UUD 1945.

Hal ini seolah menunjukkan telah terjadinya degradasi fungsi utama UUPA yang pada awal penyusunannya dicita-citakan sebagai lex generalis atas pengaturan sumber daya alam kemudian seolah menjadi sederajat dengan perundang-undangan sektoral lainnya, sehingga terjadi perubahan peranan atas UUPA dari lex generalis menjadi lex specialis yang hanya mengatur pertanahan. Terdapat perbedaan-perbedaan yang menunjukkan ditinggalkannya cita dan prinsip-prinsip yang ada di dalam UUPA oleh undang-undang sektoral antara lain: 1. Orientasi; 2. Keberpihakan; 3. Pengelolaan dan implementasinya; 4. Perlindungan atas Hak Asasi Manusia (HAM); 5. Pengaturan tentang pemerintahan yang baik; 6 . Hubungan antara orang dan SDA; 7. Hubungan antara negara dan SDA. ${ }^{4}$

Akibat yang ditimbulkan atas pengabaian tersebut ialah timbulnya ketidaksinkronisasi undangundang sektoral dengan yang lain ditunjukkan dalam Ketetapan MPR RI No. IX/MPR/2001 tentang Pembaharuan Agraria dan Pengelolaan Sumber Daya Alam (TAP MPR RI No. IX/MPR/2001). Terdapat dua pilihan yang dapat diberikan untuk menyempurnakan UUPA, yakni yang pertama meletakkan UUPA sebagai lex generalis tetap sebagaimana fungsi awalnya atau menyempurnakan UUPA sebagai lex specialis. Penyempurnaan UUPA sebagai lex specialis perlu dilakukan untuk melengkapi kekurangan-kekurangan yang ada di dalam UUPA dan perbaikan atas multi tafsir yang timbul akibat disimpanginya falsafah dan prinsip-prinsip yang ada di dalam UUPA. Atas dua alternatif tersebut, pilihan yang saat ini dipilih adalah penyempurnaan UUPA dan menjadikannya sebagai lex specialis, dengan

\footnotetext{
${ }^{4}$ Sumardjono Maria, Ismail Nurhasan, Rustiadi Ernan, Damai Abdullah Aman. (2011). Pengaturan Sumber Daya Alam di Indonesia, Antara yang Tersurat dan Tersirat. Yogyakarta: Fakultas Hukum UGM bekerjasama dengan Gadjah Mada University Press, h. 23.
} 
tugas baru yakni perlunya dibentuk suatu peraturan perundang-undangan tentang SDA yang bersifat lex generalis. Hal ini dimaksudkan agar perundangundangan tersebut bisa dijadikan pedoman bagi undang-undang sektoral lainnya, yang hasil akhirnya adalah terciptanya suatu pada hukum di bidang SDA. ${ }^{5}$

Kelemahan UUPA lainnya adalah belum mampunya UUPA dalam mengakomodir perkembangan ilmu, sosial, politik, budaya, dan ekonomi serta yang terpenting adalah kebutuhan masyarakat itu sendiri. Hal ini terlihat pada pergeseran paradigma yang sering terjadi di masyarakat akibat konflik perebutan Hak Milik, penguasaan dan penggunaan tanah akibat ketimpangan dan ketidakadilan struktur pemilikan dan pemilikan tanah. Adanya konversi lahan dapat mengancam ketahanan pangan, bencana alam, dan kerusakan lingkungan. Oleh karena itu, diperlukan distribusi dan redistribusi lahan untuk tujuan pertanian dan non-pertanian melalui reformasi akses. Selain itu, pengembangan pembangunan di ruang bawah tanah perlu untuk diatur dalam suatu aturan perundangundangan, diberlakukannya asas-asas pemerintahan yang baik secara konsisten dalam mengola pertanahan, penyelesaian konflik atau sengketa pertanahan secara masif dan berkeadilan dengan dibentuknya pengadilan pertanahan sebagai tempat bagi mayarakat yang hendak mencari keadilan. Beberapa hal tersebut menjadi poin yang penting untuk diperhatikan karena merupakan beberapa contoh permasalahan yang dihadapi di bidang pertanahan sehingga perlu untuk dilakukannya "reforma agraria" atau "pembaruan agraria". Pasal 1 Perpres No. 86 Tahun 2018 tentang Reforma Agraria (Perpres 86/2018) dijelaskan Reforma Agraria merupakan sebuah proses penataan kembali struktur atas penguasaan, pemilikan, penggunaan, dan pemanfaatan tanah dengan mengedepankan prinsip keadilan. Sehingga tercipta kemakmuran bagi seluruh lapisan masyarakat.

\section{RUMUSAN MASALAH}

Berdasarkan pendahuluan di atas, maka yang menjadi permasalahan adalah: Tujuan reforma agraria dalam menjamin pemerataan sosial ekonomi masyarakat secara menyeluruh, serta Reforma agraria

\footnotetext{
5 Sumardjono Maria. “Quo vadis UUPA”. opini dalam SKH Kompas. Jakarta, 24 September 2010, h. 12.
}

sebagai dasar dalam pembaharuan hukum agraria nasional dalam rangka mewujudkan kesejahteraan rakyat, petani dan kaum miskin (kota).

\section{KERANGKA KONSEPTUAL}

Reforma Agraria Dalam Menjamin Pemerataan Sosial Ekonomi Masyarakat Secara Menyeluruh

Reforma Agraria, Penataan kembali Struktur penguasaan, pemilikan, penggunaan, dan pemanfaatan tanah yang lebih berkeadilan melalui penataan aset dan disertai dengan penataan akses untuk kemakmuran rakyat Indonesia. Reforma Agraria mengatasi berbagai persoalan umum di Bidang Agraria, Sosial, Ekonomi, Politik, Pertahanan dan Keamanan, yaitu: 1. Ketimpangan penguasaan, pemilikan, penggunaan dan pemanfaaatan tanah; 2. Sengketa dan Konflik Agraria; 3. Alih fungsi lahan pertanian yang masif; 4 . Turunnya kualitas lingkungan hidup; 5. Kemiskinan dan Pengangguran; 6. Kesejahteraan Sosial.

Reforma Agraria merupakan salah satu Program Prioritas Nasional yang ditingkatkan Pemerintah Jokowi-JK dalam upaya membangun Indonesia dari pinggir serta meningkatkan kwalitas hidup; sebagaimana terkandung dalam Nawa Cita JokowiJK. Menilik sebelumnya pada UUPA Tahun 1960, terdapat tiga tujuan mulia yang ingin dicapai: Menata ulang struktur agraria yang timpang jadi berkeadilan; Menyelesaikan konplik agraria; Menyejahterakan rakyat setelah reforma agraria dijalankan.

Reforma Agraria secara fundamental memberi program yang dapat menuntaskan masalah kemiskinan masyarakat desa, meningkatkan kesejahteraan dengan kemandirian pangan nasional, meningkatkan produktivitas tanah, memberikan pengakuan hak atas tanah yang dimiliki baik secara pribadi, negara dan tanah milik umum yang pemanfaatannya untuk memenuhi kehidupan masyarakat. Reforma Agraria bentuknya ada tiga, yaitu: legalisasi aset, retribusi tanah dan perhutanan sosial. ${ }^{6}$

Reforma Agraria Sebagai Dasar Dalam Pembaharuan Hukum Agraria Nasional Dalam Rangka Mewujudkan Kesejahteraan Rakyat, Petani dan Kaum Miskin (Kota)

${ }^{6}$ Kominfo. Reforma Agraria Menjamin Pemerataan Sosial Ekonomi Masyarakat Secara Menyeluruh. Agustus 2018, h. 1. 
Reforma Agraria merupakan agenda besar bangsa yang membutuhkan perencanaan penyelenggaraan yang cermat guna memastikan tercapainya tujuan. Secara garis besar, mekanisme penyelenggaraan reforma agraria mencakup empat lingkup kegiatan utama, yakni (1) penetapan obyek; (2) penetapan subyek; (3) mekanisme dan delevery system reforma agraria; dan (4) access reform. ${ }^{7}$

Republik Indonesia sejak lama telah memiliki lembaga yang memiliki tugas dan kewenangan di bidang agraria. Saat ini Badan Pertanaha Nasional (BPN) sebagai Lembaga Pemerintah Non Departemen (LPND), dianggap sebagai leading sector pembangunan pertanahan nasional. BPN telah merencanakan "Empat Prinsip Pertanahan" yang memuat: 1. Pertanahan harus berkontribusi secara nyata untuk meningkatkan kesejahteraan rakyat, dan melahirkan sumber-sumber baru kemakmuran rakyat; 2. Pertanahan harus berkontribusi secara secara nyata untuk meningkatkan tatanan kehidupan bersama yang lebih berkeadilan dalam kaitannya dengan pemanfaatan, penggunaan pengguasaan, dan pemilikan tanah; 3. Pertanahan harus berkontribusi secara nyata dalam menjamin keberlanjutan sistem kemasyarakatan, kebangsaan, dan kenegaraan Indonesia dengan memberikan akses seluas-luasnya pada generasi akan datang pada sumber-sumber ekonomi masyarakat, terutama tanah; 4. Pertanahan harus berkontribusi secara nyata dalam menciptakan tatanan kehidupan bersama secara harmonis dengan mengatasi berbagai sengketa dan konflik pertanahan di seluruh tanah air, dan menata sistem pengelolaan yang tidak lagi melahirkan sengketa dan konflik. ${ }^{8}$

Kondisi eksisting hari ini mengindikasikan bahwa persoalan utama Reforma Agraria memang masih soal redistribusi lahan yang sering disederhanakan menjadi Land Reform serta pemanfaatan tanah terlantar terutama milik negara. Pemanfaatan tanah terlantar terutama milik negara dalam banyak hal

\footnotetext{
${ }^{7}$ Muhammad Ilham Arisaputra. (2015). "Access Reform Dalam Kerangka Reforma Agraria Untuk Mewujutkan Kesejahteraan Rakyat”. Disertasi. Surabaya: Fakultas Hukum UNAIR Surabaya, h. 236.

${ }^{8}$ Aristiono Nugroho. (2012). Kepercayaan Masyarakat dan Empat Prinsip Pertanahan.
}

kasus menjadi persoalan paling banyak terjadi dalam Reforma Agraria di Indonesia. ${ }^{9}$

\section{METODE PENELITIAN}

Penelitian itu adalah penelitian hukum, Peter Mahmud Marzuki berpendapat bahwa penelitian hukum adalah suatu proses untuk menemukan aturan hukum, asas hukum dan doktrin hukum untuk menyelesaikan masalah hukum. ${ }^{10}$ Pendekatan yang digunakan adalah pendekatan perundang-undangan (statute approach), sebagai sebuah pendekatan yang dilakukan dengan cara mengkaji norma-norma yang terdapat dalam ketentuan perundang-undangan.

Sumber bahan primer yang digunakan dalam penelitian ini adalah Undang-Undang Dasar Negara Republik Indonesia Tahun 1945 (UUD NRI 1945), Undang-Undang Nomor 5 Tahun 1960 tentang Peraturan Dasar Pokok-Pokok Agraria (UUPA), Ketetapan MPR RI No. IX/MPR/2001 tentang Pembaharuan Agraria dan Pengelolaan Sumber Daya Alam (TAP MPR RI No. IX/MPR/2001), dan Peraturan Presiden Republik Indonesia Nomor 86 Tahun 2018 tentang Reforma Agraria (Perpres 86/2018).

Sedangkan bahan hukum sekunder yang digunakan penulis yaitu publikasi-publikasi di bidang hukum namun bukan dokumen resmi, yaitu: buku, jurnal, dan komentar-komentar.

\section{PEMBAHASAN}

\section{Tujuan Pembaruan Agraria di Indonesia dalam Menjamin Pemerataan Sosial Ekonomi Masyarakat Secara Menyeluruh}

Mengacu pada tujuan pembaharuan agraria yang terdapat pada TAP MPR RI Nomor IX/MPR/2001 memiliki tujuan yaitu mengurangi kemiskinan, memperbaiki akses masyarakat kepada sumbersumber ekonomi (tanah), penataan ulang kesenjangan atas penguasaan kepemilikan, penggunaan, pemanfaatan tanah, dan sumber-sumber agraria; dan mengurangi sengketa pertanahan maupun agraria. TAP MPR RI Nomor IX/MPR/2001 menjadi

\footnotetext{
${ }^{9}$ Febrie Hastiyanto. "Perencanaan Pembangunan dan Gerakan Sosial Dalam Reforma Agraria di Indonesia". Kybernan: Jurnal Studi Kepemerintahan. Vol. 4 No. 2 Bulan September 2019, h. 25.

${ }^{10}$ Peter Mahmud Marzuki. (2020). Penelitian Hukum, Cetakan ke 6. Jakarta: Kencana Prenada Media Group, h. 35.
} 
salah satu kunci penting dalam kebijakan agraria di Indonesia karena alasan-alasan sebagai berikut:

1. TAP MPR RI Nomor IX/MPR/2001 sebagai arah kebijakan strategis dimana didalamnya mengandung perubahan atas visi dan misi agraria, sehingga menghadirkan politik hukum agraria yang lebih mengutamakan masyarakat.

2. Sebagai dasar hukum peraturan perundangundangan maupun kebijakan agraria setelahnya. Penerapan TAP MPR RI Nomor IX/MPR/2001 harus diperhatikan dalam penyusunan kebijakankebijakan di bidang agraria, sehingga tidak meninggalkan visi misi yang telah diubah menjadi manusiawi di poin pertama. ${ }^{11}$

Sedangkan dalam Perpres 86/2018 lebih berfokus pada dilakukannya legalisasi tanah, redistribusi tanah dan pemberdayaan terhadap masyarakat. Hal ini seolah menyimpang dari cita reforma agraria itu sendiri, yang mana salah satu sumber permasalahannya adalah sengketa kepemilikan tanah. Pengabaian tersebut semakin terlihat jelas dalam Pasal 17 angka (3) Perpres 86/2018 yang mana ditegaskan bahwa "Ketentuan lebih lanjut mengenai penanganan sengketa dan konflik agraria diatur dengan Peraturan Menteri”.

Pembentukan kebijakan seolah menjadi setengah-setengah dengan tidak diaturnya lebih lanjut mengenai konflik agraria dalam Perpres 86/2018, hal ini menjadi asalan terjadinya kekosongan norma. Sengketa agraria yang merupakan permasalahan utama yang dijumpai sebagai permasalahan nasional di bidang agraria, sudah sepatutnya mendapatkan perhatian. Sehingga dalam dalam norma hukum positif tersebut ketika telah dilakukan pengesahan dan diimplementasikan terhadap masyarakat, tidak hanya sebatas norma substansial saja. Dimana di dalamnya harus sudah terdapat norma prosedural dan struktur hukum yang akan menjamin bahwa pelaksanaannya berjalan sesuai dengan tujuan dari pembentukan aturan hukum itu sendiri. Dengan diaturnya penyelesaian sengketa agaria di Perpres 86/2018 tentunya akan menjamin kepastian hukum dan memberikan keadilan bagi mereka yang merasa dirugikan hak-haknya. Mengingat dewasa ini

${ }^{11}$ Ni Luh Ariningsih Sari, I Wayan Suwanda. "Kebijakan di Era Pemerintahan Joko Widodo dan Jusuf Kalla (Perspektif Politik Hukum dan Agraria)". Jurnal Unmasmataram. Fakultas Hukum UNMAS Denpasar PSDKU Mataram. Volume 13 Nomor 2 September 2019, h. 239. permasalahan yang sengketa agraria merupakan salah satu sumber kesenjangan dalam kepemilikan tanah.

Dalam Perpres 86/2018 memang telah mengatur mengenai penyelesaian pertanahan dalam Bab IV tentang "Penanganan Sengketa dan Konflik Agraria dengan membentuk Gugus Tugas Reforma Agraria secara berjenjang". Namun dalam ketentuan ini hanya terbatas pada para pihak yang dilibatkan dalam penyelesaian sengketa atau konflik dan selanjutnya mendelegasikan pengaturan lebih lanjut kepada Peraturan Menteri. Hal ini menunjukkan bahwa Perpres $86 / 2018$ belum dapat menyelesaikan permasalahan secara keseluruhan dan perlu untuk segera dibentuknya Peraturan Menteri. Hal ini menuntut pemerintah untuk lebih berhati-hati dalam menyusun kebijakannya, utamanya dalam bidang agraria, sehingga tidak menimbulkan inkonsistensi ataupun tumpang tindihnya peraturan perundangundangan sebagai suatu permasalahan yang baru.

Sehingga dapat disimpulkan bahwa tujuan utamanya secara umum dari pembaharuan agaria adalah untuk merubah strukrtur masyarakat, yang semula merupakan warisan stelsel feodalisme dan kolonialisme pada masa Belanda menjadi susunan masyarakat yang lebih adil dan merata. Sedangkan secara khusus bertujuan agar masyarakat dapat lebih mandiri karena kepemilikian aset tersebut, memberikan peluang kepadanya untuk mengolah tanah, sehingga pengangguran dapat berkurang dan taraf hidup masyarakat dapat meningkat.

Pada 24 September 1961, pemerintah mulai melaksanakan reformasi agraria. Ini dimulai dengan pembentukan kepanitiaan di Daerah Otonom yang bertugas mendaftarkan penguasaan tanah yang sudah melebihi batas. Dalam kebijakan-kebijakan lanjutan yang disusun oleh Pemerintah diindikasikan bahwa pengaturan masalah agraria tidak ditujukan untuk penduduk secara keseluruhan, tetapi untuk memfasilitasi modal asing. Penyelesaianpenyelesaian atas permasalahan pembaharuan agraria memiliki hambatan-hambatan yang menyebabkan pembaharuan agraria itu sendiri tidak kunjung selesai. Hambatan-hambatan tersebut antara lain:

1. Ketidakcakapan pemerintah dalam memahami secara mendetail perihal permasalahan agraria.

2. Tidak adanya komitmen dalam melaksanakan pembaharuan agraria yang dibuktikan dengan Rancangan Undang-undang Agraria sebagai 
pelaksanaan Keppres No. 34/2003 ternyata bukan "menyempurnakan" tetapi malah "merubah" UUPA.

3. Keterikatan pemerintah atas hutang luar negeri, perjanjian-perjanjian internasional, dan pemikiran-pemikiran neo-liberal.

4. Kesadaran masyarakat yang masih rendah, sehingga mudah untuk berselisih satu sama lain.

Pelaksanaan Land Reform di Indonesia pada tahun 1960-an berfokus pada penataan tanah-tanah pertanian, dengan memberikan ketentuan terkait batas maksimal atas luas penguasaan tanah pertanian, dan melakukan redistribusi (pembagian ulang). Adanya perbedaan kepentingan dan nilai yang tidak sesuai dengan falsafah maupun prinsip UUPA dapat ditemukan dengan melakukan penelusuran ketentuan peraturan perundang-undangan pertanahan yang lahir sebagai bentuk peraturan pelaksanaan UUPA. ${ }^{12}$

Penafsiran yang menyimpang dari falsafah ataupun tujuan utama adanya UUPA pada akhirnya menimbulkan permasalahan baru di bidang pertanahan itu sendiri, yang dampak akhirnya adalah terjadi sengketa pertanahan yang sangat marak hingga menyinggung sisi HAM.

Prinsip-prinsip dasar yang ada di dalam UUPA telah menunjukkan beberapa isu pascareformasi, meskipun hal tersebut masih belum sempurna. Hal ini disebabkan karena masih terdapat permasalahanpermasalahan yang belum diatur di dalam prinsipprinsip dasar UUPA. Dalam rumusan prinsip-prinsip pembaruan agraria tetap berpedoman pada prinsipprinsip dasar yang ada di dalam UUPA, bahkan dalam rumusan pembaruan agraria tersebut dalam beberapa aspek justru memberikan penguatan atas prinsip-prinsip dasar UUPA yang cenderung lemah. Berikut prinsip-prinsip yang dapat disimpulkan dari pembaruan agraria sebagaimana diatur dalam TAP MPR RI No. IX/MPR/2001 adalah sebagai berikut: 1. Mengutamakan keutuhan Negara Kesatuan Republik Indonesia; 2. Penghormatan dan perlindungan atas HAM; 3. Penghormatan terhadap supremasi hukum; 4. Kesejahteraan masyarakat; 5. Mengembangkan demokrasi, kepatuhan terhadap hukum, mengoptimalkan transparansi dan partisipasi masyarakat; 6. Mewujudkan keadilan dalam

12 Ismail Nurhasan. (2007). Perkembangan Hukum Pertanahan, Pendekatan Ekonomi Politik. Jakarta: HuMa dan Magister Hukum UGM, h. 4. penguasaan, pemilikan, penggunaan, eksploitasi dan konservasi sumber daya pertanian/alam yang tidak lagi mempertimbangkan gender; 7. Menjaga keberlanjutan, sehingga bermanfaat bagi generasi sekarang dan yang akan datang; 8. Melaksanakan fungsi sosial, melestarikan, dan fungsi ekologis sesuai dengan kondisi sosial budaya setempat; 9. Meningkatkan koherensi dan koordinasi antar sektor pembangunan dan daerah dalam pelaksanaan reformasi pertanian dan pengelolaan sumber daya alam; 10. Mengakui, menghormati dan melindungi hak-hak masyarakat adat dan keanekaragaman budaya bangsa terkait pertanian/sumber daya alam; 11. Mengupayakan keseimbangan antara hak dan kewajiban negara, pemerintah (pusat, provinsi, kabupaten/kota dan desa atau sederajat), masyarakat dan perseorangan; 12. Pelaksanaan desentralisasi dalam bentuk pembagian kewenangan di tingkat nasional, provinsi, kabupaten/kota, dan desa atau setingkat dengan pengalokasian dan pengelolaan sumber daya alam.

Ida Nurlinda ${ }^{13}$ dalam penulisan disertasinya menyederhanakan prinsip pembaharuan agraria dari 12 prinsip menjadi tiga prinsip pembaharuan agraria, yaitu keadilan, demokrasi, dan berkelanjutan. Ketiga prinsip tersebut merupakan jiwa dari UUPA sebagaimana ditegaskan dalam prinsip dasarnya.

Penyusunan RUU Pertanahan yang dilakukan dengan didasarkan pada falsafah maupun prinsipprinsip agraria akan mempermudah untuk mencapai cita dari UUPA itu sendiri, sehingga dapat melengkapi dan menjelaskan secara jelas perihal pokok-pokok yang belum diatur di dalam UUPA dan memberikan pembatasan atas penafsiran yang tidak sesuai dari falsafah maupun prinsip pokok agraria. Hal ini apabila dapat dilakukan dengan baik, maka akan berbanding lurus dengan kesejahteraan yang akan diterima masyarakat, karena sengketa di bidang pertanahan dapat diantisipasi agar tidak terjadi lagi.

\section{Reforma Agraria Sebagai Dasar Bagi Pembangunan Nasional Indonesia Baru}

Dalam dokumen "Petisi Cisarua" sejumlah pakar dan aktivis pembaharuan agraria telah mengingatkan bahwa jika hendak menjalankan reforma agraria di Indonesia jangan lah "setengah-

13 Nurlinda Ida. (2009). Prinsip-Prinsip Pembaruan Agraria, Perspektif Hukum. Jakarta: Rajawali Press, h. 45. 
setengah", tetapi jadikan reforma agraria sebagai dasar bagi pembangunan ekonomi (nasional) bagi Indonesia baru. ${ }^{14}$ Sesungguhnya reforma agraria yang berhasil dalam pengalaman banyak negara seperti di Jepang, Taiwan, Cina, Korea Selatan, Mesir, dan sebagainya adalah yang menempatkannya sebagai dasar bagi pembangunan ekonomi secara nasional yang kemudian menjadikannya basis penting bagi pertumbuhan industri nasional yang kuat.

Dalam hal ini Reforma Agraria dapat diartikan sebagai suatu upaya sistematik, terencana dan dilakukan secara relatif cepat, dalam jangka waktu tertentu dan terbatas, untuk menciptakan kesejahteraan dan keadilan sosial serta menjadi pembuka jalan bagi pembentukan masyarakar 'baru' yang demokratis dan berkeadilan; yang dimulai dengan langkah menata ulang penguasaan, penggunaan, dan pemanfaatan tanah dan kekayaan alam lainnya, kemudian disusul dengan sejumlah program pendukung lain untuk meningkatkan produktivitas petani khususnya dan perekonomian rakyat pada umumnya. ${ }^{15}$

14 Poniman, et.al. (2005), Petisi Cisarua (Bandung: Pergerakan), Lihat juga: Bachriadi, Dianto (1999), Pembaharuan Agraria 1999, makalah untuk Seminar "Mendesakan Agenda Pembaharuan Agraria dalam Sidang Umum (SU) MPR 1999" yang diselenggarakan oleh KPA, ELSAM, dan Lab, SosiologiAntropologi IPB di Jakarta, 22 September 1999; dan Wiradi, Gunawan (2000). Reforma Agraria: Perjalanan yang Belum Berakhir (Yogyakarta: Insist Press-KPA-Pustaka Pelajar). Dalam hal ini patut juga disampaikan adanya sejumlah keraguan diri para pakar bahwa sesungguhnya momentum bagi pelaksanaan reforma agraria yang sejati sesungguhnya belum lagi terbentuk,meskipun SBY-JK selaku kandidat calon presiden dan calon presiden telah mencanangkannya sebagai bagian dari Visi dan Misi yang mereka ajukan ke KPU dan publik intuk menjalankan program ini jika mereka terpilih sebagai pimpinan nasional yang baru pasca Pemilu 2004, Gunawan Wiradi, salah seorang pakar agraria di Indonesia dan mantan anggota Dewan Pakar Konsorsium Pembaharuan Agraria (KPA), dalam berbagai kesempatan sering mengatakan bahwa momentum yang paling pas bagi pelaksanaan reforma agraria yang sejati sesunggunya telah terlewat dan tidak berhasil dimanfaatkan dengan baik oleh para pemimpin negeri ini ketika pemerintahan Orde Lama mengesahkan UUPA 1960 dan mulai menjalankan program landreform setahun kemudian. Dalam pandangannya, pada saat itu sejumlah prasyarat bagi dilaksanakan reforma agraria yang sejati di Indonesia relatif tersedia, tetapi tidak pada saat ini. Mengenai sejumlah persaratan ini lihat: Russel (1977), Land Reform: A World Survey (Boul-der: Westview Press); dan Wiradi (2000), Reforma Agraria.

${ }^{15}$ Dianto Bachriadi, Reforma Agraria untuk Indonesia: Pandangan Kritis tentang Program Pembaharuan Agraria Nasional (PPAN) atau Redistribusi Tanah ala Pemerintahan $S B Y$.
Agenda Reforma Agraria di dalam sejarah bangsa Indonesia memiliki perjalanan yang panjang dan sejalan dengan agenda pembentukan bangsa dan negara. Sejak tahun 1946 Indonesia sudah menjalankan program landreform.

Secara umum, ada enam elemen pokok program landreform sebagaimana diamanahkan oleh UUPA yaitu: 1. Larangan untuk menguasai tanah pertanian yang melampaui batas (pembatasan pemilikan maksimal); 2. Larangan pemilikan tanah secara absentee; 3. Restribusi tanah-tanah yang melampaui batas maksimum, tanah-tanah yang terkena ketentuan absentee, tanah-tanah bekas swapraja dan tanah-tanah negara lainnya; 4. Pengaturan kembali perjanjian bagi hasil tanah pertanian; 5. Penetapan batas minimum pemilik tanah pertanian, disertai larangan untuk melakukan perbuatan-perbuatan yang mengakibatkan pemecahan pemilikan tanah-tanah pertanian menjadi bagian-bagian yang terlampau kecil.

Implementasi kebijakan landreform ini pada masa lalu ternyata masih sangat terbatas dan belum dapat memenuhi tujuan-tujuan seperti yang diharapkan. ${ }^{16}$

\section{PENUTUP \\ Kesimpulan}

Berdasarkan pembahasan di atas, maka dapat diberikan kesimpulan sebagai berikut:

Tujuan Reforma Agraria pada dasarnya adalah untuk merestrukturisasi tatanan yang ada di dalam masyarakat, sehingga masyarakat dapat merasakan keadilan dan kesamarataan di bidang pertanahan.

Dalam pelaksanaan reforma agraria terdapat beberapa tahapan yakni pembentukan panitia di tingkat daerah otonom, yang bertugas melakukan pendaftaran kepemilikan tanah yang melebihi batas maksimal yang mana tujuannya adalah kesejahteraan rakyat. Namun dalam perkembangannya pelaksanaan pembaharuan agraria tersebut mengalami hambatanhambatan yang menyebabkan tujuan utama dari pembaharuan agraria belum tercapai.

\section{Rekomendasi}

Pemerintah dalam menyusun peraturan perundang-undangan harus tetap mematuhi rambu-

${ }^{16}$ Putri Ayu Rezki Utami. Kajian Hukum Pelaksanaan Program Pembaharuan Agraria Nasional Di Kabupaten Serdang Bedagai, h. 5. 
rambu yang ada di bidang pertanahan, utamanya falsafah dan prinsip-prinsip dasar yang ada di dalam UUPA.

Dilakukan perbaikan dan evaluasi terhadap kebijakan-kebijakan yang disusun setelah UUPA, sehingga tujuan dari pembaharuan agraria dapat berjalan sebagaimana mestinya dan dapat memberikan dampak kesejahteraan kepada seluruh lapisan masyarakat.

\section{DAFTAR PUSTAKA}

\section{Peraturan Perundang-undangan:}

Undang-Undang Dasar Tahun 1945.

Undang-Undang Nomor 5 Tahun 1960 tentang Peraturan Dasar Pokok-Pokok Agraria.

Undang-Undang No. 5 Tahun 1967 tentang Kehutanan (telah diganti dengan UndangUndang No. 41 Tahun 1999).

Undang-Undang No. 11 Tahun 1967 tentang Pertambangan (telah diganti dengan UndangUndang No. 22 Tahun 2001).

Undang-Undang No. 11 Tahun 1974 tentang Pengairan (telah diganti dengan UU No. 7 Tahun 2004 tentang Sumber Daya Air).

Ketetapan MPR RI No. IX/MPR/2001 tentang Pembaruan Agraria dan Pengelolaan Sumber Daya Alam.

Peraturan Presiden Republik Indonesia Nomor 86 Tahun 2018 Tentang Reforma Agraria.

\section{Buku:}

Boedi Harsono. (1999). Hukum Agraria Indonesia, Sejarah Pembentukan UUPA, Isi dan Pelaksanaannya. Jakarta: Djambatan.

Ismail Nurhasan. 2007. Perkembangan Hukum Pertanahan, Pendekatan Ekonomi Politik. Jakarta: HuMa dan Magister Hukum UGM.

Nurlinda Ida. 2009. Prinsip-Prinsip Pembaruan Agraria, Perspektif Hukum. Jakarta: Rajawali Press.

Peter Mahmud Marzuki. (2020). Penelitian Hukum, Cetakan ke 6. Jakarta: Kencana Prenada Media Group.

Soetiknjo Iman. (1987). Proses Terjadinya UUPA, Peranserta Seksi Agraria Universitas Gadjah Mada. Yogyakarta: Gadjah Mada University Press.

\section{Jurnal/Artikel:}

Aristiono Nugroho. (2012). Kepercayaan Masyarakat dan Empat Prinsip Pertanahan.

Dianto Bachriadi, Reforma Agraria untuk Indonesia: Pandangan Kritis tentang Program Pembaharuan Agraria Nasional (PPAN) atau Redistribusi Tanah ala Pemerintahan SBY.

Febrie Hastiyanto. "Perencanaan Pembangunan dan Gerakan Sosial Dalam Reforma Agraria di Indonesia". Kybernan: Jurnal Studi Kepemerintahan. Vol. 4 No. 2 Bulan September 2019.

Kominfo. Reforma Agraria Menjamin Pemerataan Sosial Ekonomi Masyarakat Secara Menyeluruh. Bulan Agustus 2018.

Ni Luh Ariningsih Sari, I Wayan Suwanda. "Kebijakan di Era Pemerintahan Joko Widodo dan Jusuf Kalla (Perspektif Politik Hukum dan Agraria)". Jurnal Unmasmataram. Fakultas Hukum UNMAS Denpasar PSDKU Mataram. Volume 13 Nomor 2 September 2019.

Poniman, et.al. (2005). Petisi Cisarua. Bandung: Pergerakan,

Putri Ayu Rezki Utami. Kajian Hukum Pelaksanaan Program Pembaharuan Agraria Nasional Di Kabupaten Serdang Bedagai.

Sumardjono Maria, Ismail Nurhasan, Rustiadi Ernan, Damai Abdullah Aman. (2011). Pengaturan Sumber Daya Alam di Indonesia, Antara yang Tersurat dan Tersirat. Yogyakarta: FH UGM dengan Gadjah Mada University Press.

Sumardjono Maria. "Quo vadis UUPA". opini dalam SKH Kompas. Jakarta, 24 September 2010.

\section{Disertasi:}

Muhammad Ilham Arisaputra. (2015). “Access Reform Dalam Kerangka Reforma Agraria Untuk Mewujudkan Kesejahteraan Rakyat". Disertasi. Surabaya: Fakultas Hukum UNAIR Surabaya. 